\title{
Radioactivity of dumps in mining areas of the Upper Silesian Coal Basin in Poland
}

\author{
B. Kozeowska*, A. Walencik, J. Dorda and W. Zipper
}

University of Silesia, Institute of Physics, Department of Nuclear Physics and Its Applications - Uniwersytecka 4 St., 40-007 Katowice, Poland

\begin{abstract}
Underground coal mining is associated with large quantities of gangue. In the past, the majority of gangue was not utilized but was placed in the vicinity of the coalmines forming cone-shaped dumps. Some of them contained even millions of tons of rock. Nowadays, environmental precautions extort larger utilization of any kind of waste materials, for example in road construction, civil engineering or as stowing in underground abandoned workings. Examination of the composition of waste dumps, including radioactivity, is thus an important issue. The paper presents results of a radiological survey carried out in several dumps located in the Upper Silesian Coal Basin in the south of Poland. Measurements of samples were carried out with the use of a gamma-ray spectrometer. Activity concentration results for the uranium and thorium decay chains are discussed.
\end{abstract}

\section{Introduction}

The Upper Silesian Coal Basin (USCB) is located in Silesia in Poland and the Czech Republic. Apart from coal it also contains a number of other minable resources (methane, cadmium, lead, silver and zinc). Resources of coal go down to a depth to 1000 meters. This area is a home of altogether 5 million people.

\footnotetext{
*E-mail: beata.kozlowska@us.edu.pl
}

This is an Open Access article distributed under the terms of the Creative Commons Attribution License 2.0, which permits unrestricted use, distribution, and reproduction in any medium, provided the original work is properly cited. 
Underground coal mining is associated with the production of great amounts of rock waste. It is estimated that for $1 \mathrm{t}$ of output coal, there is about $0.4 \mathrm{t}$ of waste material [1]. In the past, the majority of wastes, mainly gangue, was not utilized but was transported and placed in the vicinity of the coalmines forming cone-shaped dumps. Some of them contained even millions of tons of rock. Therefore, in Poland, especially in Silesia there are many coal waste dumps. Recently, there were counted 136 coal waste dumps with 750 million tons of waste in the area on the Upper Silesia region. Their total area is about $3500000 \mathrm{~m}^{2}$ [2]. For example the waste dump in Eaziska has a height of $90 \mathrm{~m}$, a surface of $30000 \mathrm{~m}^{2}$ and weight of 17 million tons. Nowadays, environmental precautions ask for larger utilization of any kind of waste materials, for example in road construction, civil engineering or as stowing in underground abandoned workings.

Prior to any use of waste materials studies are required in order to avoid any hazard, including radioactivity, for the environment and the human beings. Assessing the radioactivity of waste is quite important due to the fact that they might be used in the production of building materials for residential constructions. Figure 1 presents the location of seven dumps from where the samples were taken for these studies.

The long lasting mining industry influenced the Silesian environment and landscape. In the post-mining areas of proper management, dumps are the subject of land reclamation, which in consequence leads to formation of walking and recreational forest areas (Figure 2). However, the scenario might also be quite different. The waste stored in dumps includes in its composition a significant amount of material, mostly coal and pyrite, which is reactive. The contact of those components with oxygen leads to natural oxidation and heat production, which may cause spontaneous heating and burning of the waste. The external factors such as height and volume of the dump, the gradient of slopes and the meteorological conditions are very important, too [1]. Burning dumps are dangerous for people and also are the source of air pollution and dust in its neighborhood. When a dump burns its temperature varies between 900 and $1200{ }^{\circ} \mathrm{C}$.

Summarizing, monitoring of the dump composition, and its radioactivity, is an extremely important issue.

\section{Measurements and methods}

The studied material comprises waste samples collected from outcrops in the dumps of USCB. The samples were collected from 9 places (see Figure 1). In 


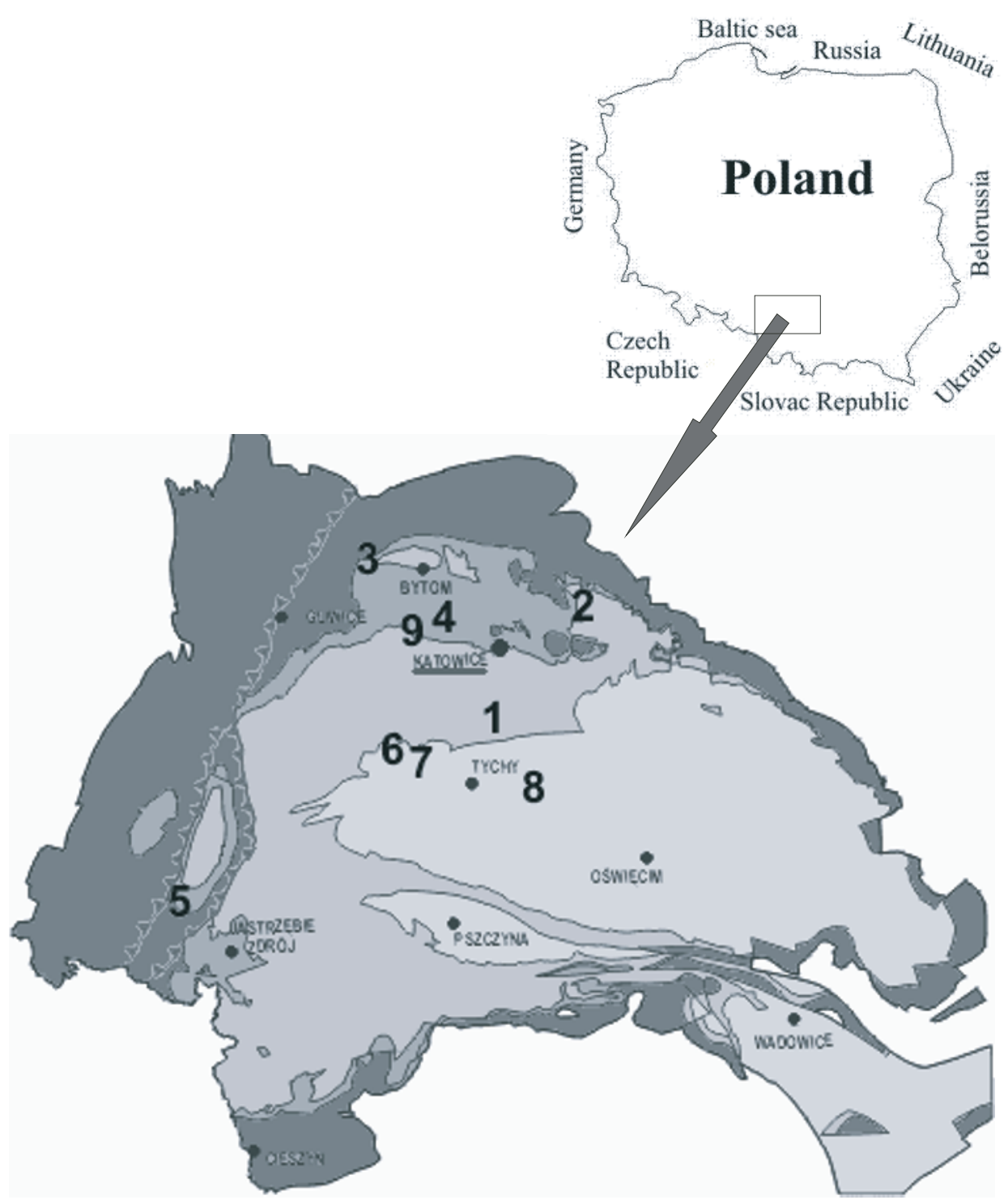

Figure 1: Location of dumps used as sampling points on the background of the geological map (post-Quaternary) of the Upper Silesian Coal Basin, including tectonic elements: 1. dump of Murcki - Staszic coal mine, Katowice, 2. dump of Saturn coal mine, Czeladź, 3. dump of Mikulczyce coal mine, Zabrze - Mikulczyce, 4. dump of Śląsk coal mine, Ruda Śląska, 5. dump of Marcel coal mine, Radlin, 6. dump "Skalny" of Bolesław Śmiały coal mine, Łaziska, 7. dump "Waleska" of Bolesław Śmiały coal mine, Laziska, 8. dump of Ziemowit coal mine, Lȩdziny, 9. dump of "Pokój" and "Florian" steal mills, Świętochłowice. 


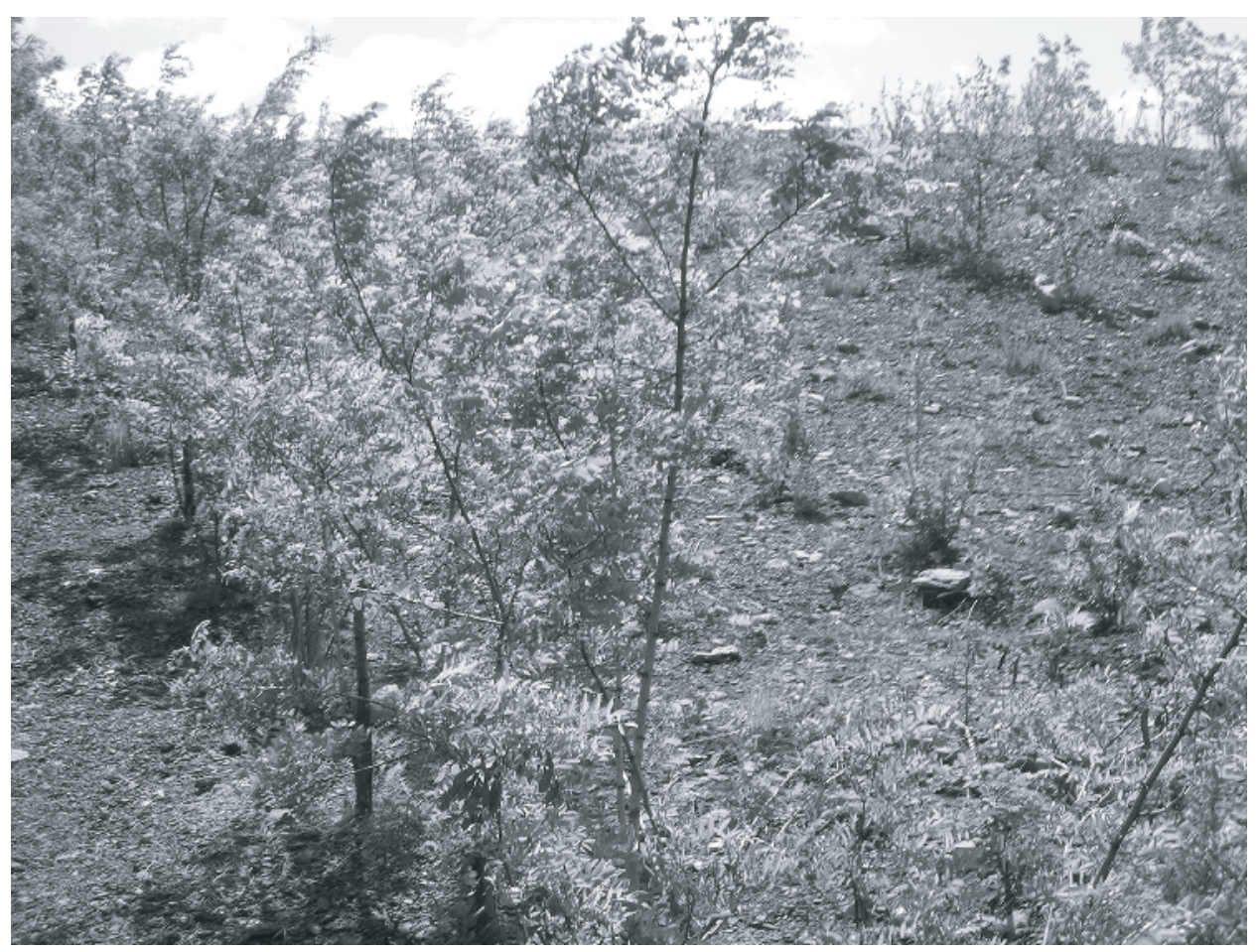

Figure 2: The coal waste dump Marcel after land reclamation (photograph by B.K.).

total, 43 samples representing different waste material were collected. The material from the Murcki-Staszic, Marcel and Waleska coal mine dumps was represented mostly by soil with slag. The Murcki-Staszic dump is nowadays being reclaimed with grass and trees slowly overgrowing its area. The material of four samples from the Skalny dump was soil, gravel, coal and gangue, whereas five samples were soil, clay and gravel. This dump is one of the biggest in the Upper Silesia and even in Europe. It was used for the last 220 years, so one can find many kinds of different materials there. Another dump with a variety of material was Saturn which was working for the last 150 years. Since 2004 the coal mine is closed and the biological recultivation into forests or meadows has been conducted in its dump. In some dumps was also stored the precipitate from ponds.

The studies of waste samples were carried out from 2005 to 2010. All measurements were performed in the Department of Nuclear Physics and Its Applications of the Institute of Physics at the University of Silesia, Katowice, Poland. Each sample was transferred to the laboratory, where it 
was analyzed, dried, crushed and ground to a fraction smaller than $0.2 \mathrm{~mm}$ for homogenization. The measurements were carried out in Marinelli geometry, in $0.6 \mathrm{dm}^{3}$ containers. The natural radioactivity of ${ }^{226} \mathrm{Ra},{ }^{232} \mathrm{Th}$ $\left({ }^{228} \mathrm{Ac}\right)$ and ${ }^{40} \mathrm{~K}$ was determined using the a semi-conductor $\mathrm{Ge}(\mathrm{Li})$ gammaray spectrometer. The spectra were analyzed with the use of the TUKAN software, version 1.4, and the GANNAS spectrum analysis program [3]. The energy calibration and the detector efficiency curves were obtained on the basis of standards prepared from certified materials from the International Atomic Energy Agency and from the Central Laboratory for Radiological Protection from Warsaw, Poland.

The activity of ${ }^{226} \mathrm{Ra}$ was calculated as the weighted mean of the values obtained directly from the $186.2 \mathrm{keV}$ line and the activities of ${ }^{214} \mathrm{~Pb}(241.9$, $295.2,351.9 \mathrm{keV})$ and ${ }^{214} \mathrm{Bi}(609.3,1120.3 \mathrm{keV})$. The determination of the presence of ${ }^{232} \mathrm{Th}$ and calculation of its activity was based on the following gamma-ray transitions: ${ }^{228} \mathrm{Ac}(338.3,911.1,968.9 \mathrm{keV})$ and ${ }^{212} \mathrm{~Pb}(238.6$, $300.1 \mathrm{keV}) .{ }^{40} \mathrm{~K}$ was calculated from the $1460 \mathrm{keV}$ line. The detection limit for the measurements calculated according to Curie method [4] was about $1 \mathrm{~Bq} \mathrm{~kg}^{-1}$ for each investigated isotope.

\section{Results and discussion}

The content of the ${ }^{226} \mathrm{Ra},{ }^{232} \mathrm{Th}$ and ${ }^{40} \mathrm{~K}$ activity concentration in the 43 samples of the Silesian coal waste dumps is graphically presented in the Figures $3 \mathrm{~A}$ and $3 \mathrm{~B}$. Some basic statistical values are presented in Table I. For comparison, mean concentrations of these radionuclides in the soils of the Silesian Voivodship are also listed.

As can be seen in Figures 3A and 3B the measured activity concentration associated with ${ }^{226} \mathrm{Ra},{ }^{232} \mathrm{Th}$ and ${ }^{40} \mathrm{~K}$ is higher for the majority of the samples than the average activity concentration of these radioisotopes in the soil in the Upper Silesia region. It must be emphasized that the sampling at particular dumps was performed randomly. The lowest levels of measured radioactivity were measured in samples collected from dumps belonging to the steel mill in Świętochłowice. For one sample, the obtained results were distinctly higher than the average values. The obtained results suggest that this high content of ${ }^{226} \mathrm{Ra},{ }^{232} \mathrm{Th}$ and also ${ }^{40} \mathrm{~K}$ is connected with the specific collection place, where probably also the precipitate from ponds was deposited. The high activity value of this particular sample suggests that prior to any use a specific examination of the material must be done. 


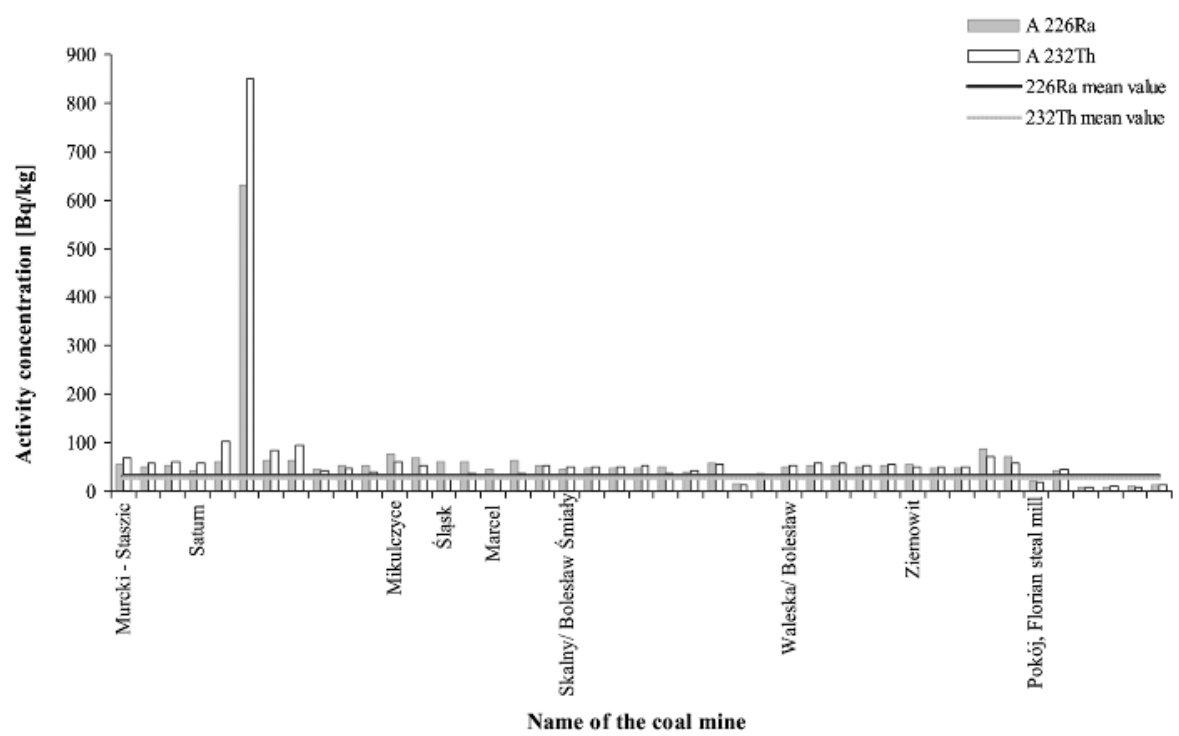

B)

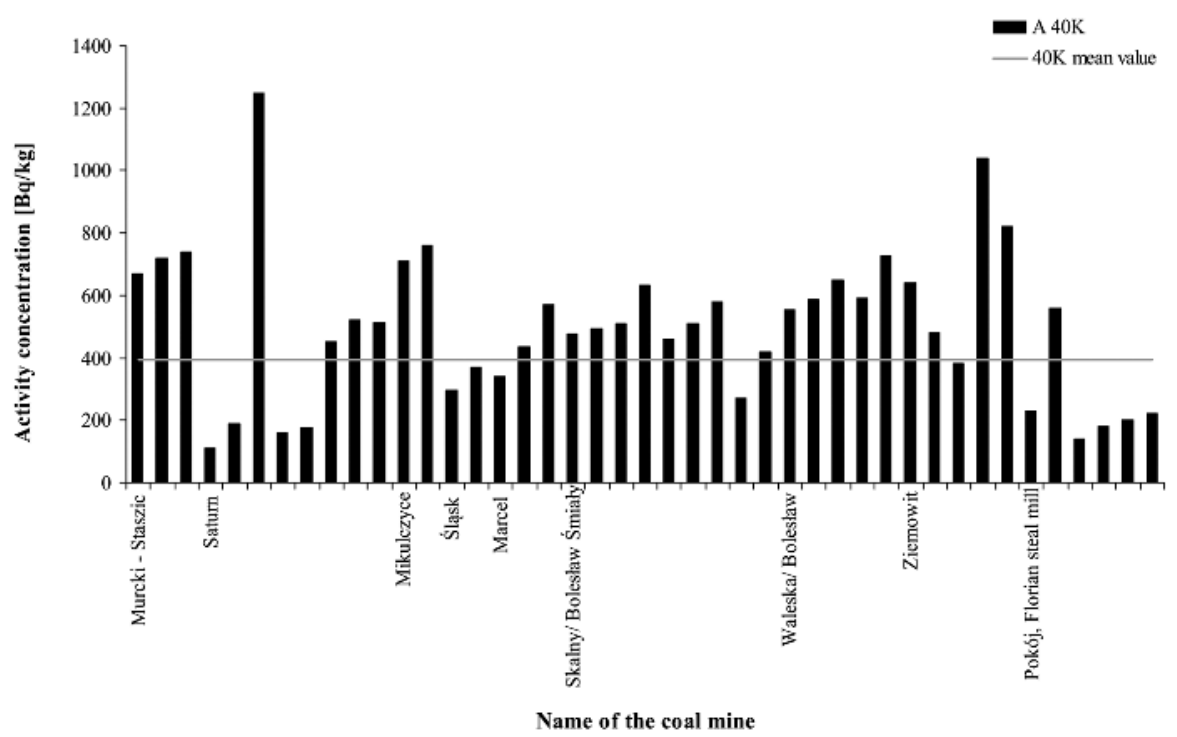

Figure 3: Comparison of A) ${ }^{226} \mathrm{Ra},{ }^{232} \mathrm{Th}$ and B) ${ }^{40} \mathrm{~K}$ activity concentration in the measured samples with the average activity concentration of these radionuclides reported for average soil (solid lines) in Upper Silesia. 
Table I: Selected statistical parameters concerning ${ }^{226} \mathrm{Ra},{ }^{232} \mathrm{Th}$ and ${ }^{40} \mathrm{~K}$ content $[\mathrm{Bq} / \mathrm{kg}]$ in the material from different coal waste dumps of USCB.

\begin{tabular}{|c|c|c|c|}
\hline Parameter & ${ }^{226} \mathrm{Ra}$ & ${ }^{232} \mathrm{Th}$ & ${ }^{40} \mathrm{~K}$ \\
\hline Number of samples & 43 & 43 & 43 \\
\hline Minimum & 8 & 8 & 110 \\
\hline Maximum & 632 & 850 & 1250 \\
\hline Arithmetic mean & 62 & 67 & 496 \\
\hline Standard deviation & 91 & 124 & 242 \\
\hline Median & 51 & 51 & 507 \\
\hline Mean for the Silesian Voivodship & 31 & 28 & 396 \\
\hline
\end{tabular}

\section{Summary and conclusions}

The mean ${ }^{226} \mathrm{Ra},{ }^{232} \mathrm{Th}$ and ${ }^{40} \mathrm{~K}$ contents in the dump samples of USCB were 62,67 and $496 \mathrm{~Bq} \mathrm{~kg}^{-1}$, respectively. These values are very close to their respective median values, which confirms their normal distribution. The obtained results concern TENORM values. The mean values are higher than average data for the soils in the Silesian Voivodship, which are around $30 \mathrm{~Bq} \mathrm{~kg}^{-1}$ for ${ }^{226} \mathrm{Ra}$ and ${ }^{232} \mathrm{Th}$ and about $400 \mathrm{~Bq} \mathrm{~kg}^{-1}$ for ${ }^{40} \mathrm{~K}$.

The results of gamma-ray measurements presented here give a piece of current information about the natural radioactivity content in samples in coal mine waste dumps in the USCB region. The majority of the collected samples present slightly elevated levels of natural radioactivity, however one can find material of distinctly higher values. Since coal mine wastes are often used in different applications, studies assessing their level of hazard for the environment and human beings are necessary.

\section{References}

[1] SUŁKOWSKI J., DRENDA J., RÓŻAŃSKI Z., WRONA P., Natural Resources Management No. 24 (3) (2008). In Polish.

[2] SIKORSKA-MAYAKOWSKA M., BARSZCZ A., GRABOWSKI D., LEWANDOWSKI P., STRZELECKI R., Natural environment and the identification of its hazards in the Silesian Voivodship (Państwowy Instytut Geologiczny, Warszawa) 2001. In Polish. 
[3] GANAAS, Nuclear Analysis Software. Part 2: Gamma Spectrum Analysis Activity Calculation and Neutron Activation Analysis, Computer Manual Series No. 3 (International Atomic Energy Agency, Vienna) 1991.

[4] CURIE L. A., Analytical Chemistry 40(3) (1968) 586-593. 